\title{
Zaburzenia mechanizmów epigenetycznych w ostrej białaczce szpikowej
}

\section{Alterations of epigenetic mechanisms in acute myeloid leukemia}

\author{
Kamil Wiśniewski ${ }^{1}$, Emilia Białopiotrowicz ${ }^{2}$, Joanna Góra-Tybor ${ }^{1}$ \\ ${ }^{1}$ Klinika Hematologii, Instytut Hematologii i Transfuzjologii, Warszawa \\ ${ }^{2}$ Pracownia Hematologii Doświadczalnej, Zakład Diagnostyki Hematologicznej, \\ Instytut Hematologii i Transfuzjologii, Warszawa
}

\begin{abstract}
Streszczenie
Regulacja epigenetyczna wptywa na ekspresje genów, nie zmieniajac zapisu sekwencji nukleotydowej kwasu deoksyrybonukleinowego (DNA). Mechanizmy epigenetyczne obejmuja zmiany struktury chromatyny wskutek metylacji DNA $i$ modyfikacji biatek histonowych oraz regulacje ekspresji genów poprzez niekodujace czasteczki kwasu rybonukleinowego. Nieprawidtowy przebieg powyższych procesów odgrywa istotna role w patogenezie ostrej biataczki szpikowej (AML). Mutacje genów kodujacych regulatory epigenetyczne wystęuja u 70\% chorych z AML i najczęściej dotyczq genów DNMT3A, TET2, IDH1/2 oraz ASXL1. Obecność lub brak mutacji w wymienionych genach może stanowić $w$ przysztości ważny czynnik prognostyczny oraz potencjalny punkt uchwytu dla terapii celowanych. W poniższym artykule omówiono znaczenie zaburzeń epigenetycznych w rozwoju AML, ich wplyw na przebieg choroby oraz możliwość wykorzystania w terapii.
\end{abstract}

Słowa kluczowe: ostra białaczka szpikowa, epigenetyka, metylacja DNA, modyfikacje histonów

Hematologia 2018; 9, 2: 100-109

\begin{abstract}
Epigenetic regulation influences gene expression without changing the nucleotide sequence of the deoxyribonucleic acid (DNA). The most important epigenetic mechanisms include DNA methylation, modifications of histone proteins and non-coding RNAs. The dysregulation of the abovementioned processes plays a significant role in the pathogenesis of acute myeloid leukemia (AML). Mutations in the genes that are essential for epigenetic regulations are common in $70 \%$ of patients with AML. The most frequent mutations involve the DNMT3A, TET2, IDH1/2 and ASXL1 genes. Their presence or absence may constitute a vital prognostic factor in the future as well as become a potential basis for targeted therapies. The present paper manifests the importance of epigenetic alterations in the development of AML and their impact on the course of the disease. The article also discusses some possibilities for the use of epigenetic modifications in the AML therapy.
\end{abstract}

Key words: acute myeloid leukemia, epigenetics, DNA methylation, histone modifications

Hematologia 2018; 9, 2: 100-109

Adres do korespondencji: Kamil Wiśniewski, Klinika Hematologii, Instytut Hematologii i Transfuzjologii, ul. Indiry Gandhi 14, 02-776 Warszawa, tel. +48 223496 324; faks +48 223496 335, e-mail: kamilwis-90@wp.pl 


\section{Wprowadzenie}

Ostra białaczka szpikowa (AML, acute myeloid leukemia) jest nowotworem złośliwym układu krwiotwórczego, w przebiegu którego dochodzi do namnażania i akumulacji komórek blastycznych wywodzących się ze zmienionych nowotworowo młodych komórek linii mieloidalnej [1, 2]. Ostra białaczka szpikowa jest najczęstszą spośród ostrych białaczek u dorosłych, a zapadalność zwiększa się po 60. roku życia. Mimo stosowania schematów intensywnej chemioterapii AML jest chorobą o niekorzystnym rokowaniu, zwłaszcza $\mathrm{w}$ grupie osób starszych, u których 5-letni czas przeżycia (OS, overall survival) wynosi zaledwie 3-8\% [3]. Wobec niedostatecznej skuteczności stosowanych dotychczas metod istnieje pilna potrzeba wprowadzenia nowych leków o odmiennych kierunkach działania [4-6].

Jednym $z$ czynników utrudniających leczenie AML pozostaje jej wyjątkowa heterogenność w zakresie zaburzeń cytogenetycznych oraz molekularnych [1, 7]. Dynamiczny rozwój metod biologii molekularnej w ostatnim okresie pozwolił zidentyfikować nowe mutacje, które są wykrywane u coraz większej liczby chorych, stając się między innymi podstawą różnych klasyfikacji rokowniczych $[8,9]$. W najnowszych badaniach dowiedziono, że zaburzenia epigenetyczne stanowią istotny mechanizm rozwoju AML [10]. W ostatnich latach pojawiły się liczne prace wskazujące na wysoką częstość mutacji genów zaangażowanych w regulację metylacji DNA i modyfikacji histonów u chorych na AML (tab. 1). Konsekwencją opisywanych mutacji epigenetycznych jest często charakterystyczny fenotyp epigenetyczny (np. zmiana profilu globalnej metylacji DNA), co może stanowić dowód na wspólny wpływ zaburzeń genetycznych oraz epigenetycznych na transformację nowotworową w AML [11, 12]. $Z$ klinicznego punktu widzenia istotny jest fakt, $\dot{z}$ e zaburzenia epigenetyczne mają charakter odwracalny, co stwarza możliwość opracowania leków niwelujących biologiczne efekty mutacji regulatorów epigenetycznych w komórce nowotworowej [13].

\section{Mechanizmy epigenetyczne i ich zaburzenia w AML}

Epigenetyka jest nauką zajmującą się opisywaniem dziedzicznych zmian ekspresji genów, które nie wynikają ze zmian w sekwencji nukleotydów DNA $[14,15]$. Główne modyfikacje epigenetyczne dotyczą metylacji DNA, modyfikacji

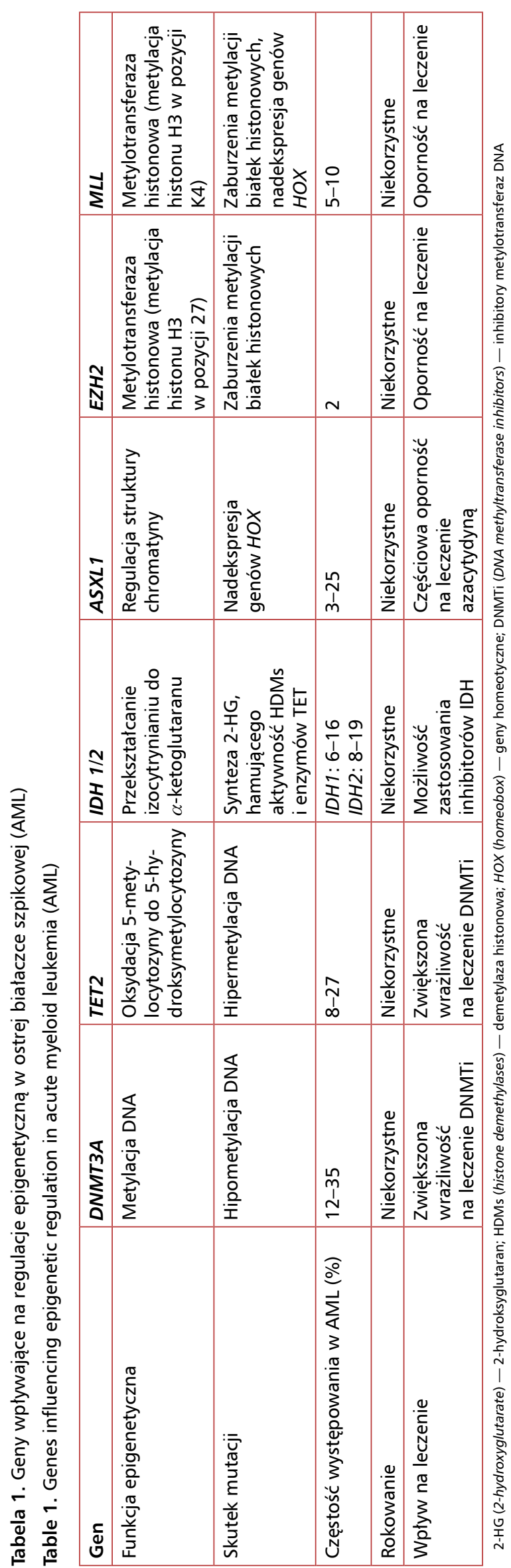




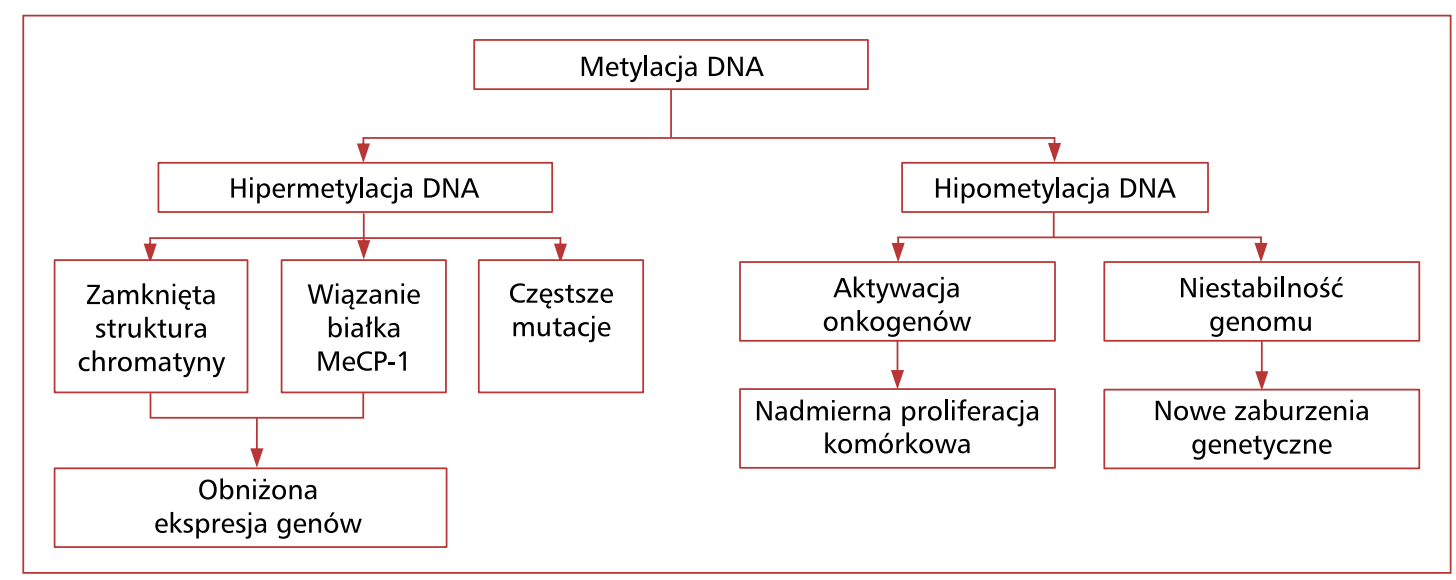

Rycina 1. Zaburzenia w metylacji DNA; MeCP-1 - białko wiążące się z metylowanymi wyspami CpG

Figure 1. Alterations in DNA methylation; MeCP-1 - methyl-CpG-binding protein 1

białek histonowych oraz regulacji genów poprzez niekodujące cząsteczki RNA (ncRNA, non-coding $R N A$ ). Zaburzenia wymienionych mechanizmów epigenetycznych mogą spowodować powstanie nieprawidłowej, zamkniętej struktury chromatyny, a w konsekwencji - deregulację aktywności transkrypcyjnej genów, przyczyniając się do leukemogenezy $[16,17]$.

\section{Metylacja DNA}

Metylacja DNA polega głównie na przyłączeniu reszty metylowej do cytozyny (rzadziej do adenozyny), co zmienia strukturę chromatyny na bardziej zwartą i w konsekwencji prowadzi do obniżenia ekspresji genu znajdującego się w poblizu zmetylowanego regionu DNA [12, 18, 19]. Reakcja metylacji DNA przebiega $z$ udziałem enzymów z grupy metylotransferaz DNA (DNMT, DNA methyltransferase) zaś za reakcje demetylacji odpowiadają enzymy TET (ten-eleven translocation) [16]. Mutacje w genach regulujących metylację DNA stwierdzono u $44 \%$ chorych na AML $[18,20]$, a ich następstwem jest zaburzenie profilu metylacji DNA (tzw. metylomu), który w pewnych regionach może ulec nadmiernej (hiper-) lub niedostatecznej (hipo-) metylacji [21].

Obszary DNA, które szczególnie często podlegają hipermetylacji w komórkach AML, to tak zwane wyspy $\mathrm{CpG}$ - krótkie odcinki DNA wyjątkowo bogate $\mathrm{w}$ cytozynę i guaninę. Wyspy $\mathrm{CpG}$ są zlokalizowane $\mathrm{w}$ regionach promotorowych genów o decydującym znaczeniu dla prawidłowego funkcjonowania komórek, jak na przykład geny supresorów nowotworzenia, które zapobiegają niekontrolowanym podziałom komórkowym [18, $22,23]$. Komórki nowotworowe o dużym stopniu metylacji wysp CpG, określa się jako CIMP ( $C p G$ -island hypermethylator phenotypes) [24]. Hipermetylacja DNA obniża ekspresję genu na co najmniej dwa sposoby. Po pierwsze, zmetylowane wyspy CpG są rozpoznawane przez białko wiążące się z metylowanymi wyspami CpG (MeCP-1, methyl-CpG-binding protein 1), którego przyłączenie osłabia ekspresję genu [25]. Po drugie, hipermetylacja DNA powoduje, że jest on ściślej owinięty wokół białek histonowych, co w znaczny sposób utrudnia jego dostęp czynnikom transkrypcyjnym i polimerazie RNA [26]. Ponadto hipermetylowane sekwencje DNA częściej ulegają mutacjom, które mogą mieć potencjalnie onkogenny charakter [27]. Obecność CIMP w zespołach mielodysplastycznych (MDS, myelodysplastic syndrome) wiąże się z gorszym rokowaniem oraz szybką progresją do AML [28].

Jednocześnie hipometylacja genomowego DNA może się przyczyniać do transformacji nowotworowej. Wykazano, że w trakcie onkogenezy dochodzi do stopniowej utraty metylacji DNA zarówno w miejscach kodujących, jak i niekodujących. Niedostateczna metylacja wywołuje niekontrolowaną aktywację onkogenów, prowadząc do nadmiernej proliferacji komórkowej. Globalna i lokalna demetylacja DNA w regionach genów promotorowych wywołuje również niestabilność genomu, która może prowadzić do powstawania nowych zaburzeń genetycznych (ryc. 1). Warto zaznaczyć, że globalna hipometylacja DNA nie jest procesem nasilonym w AML, ponieważ stwierdzono, że DNA komórek białaczkowych jest zaledwie 
o 2,7\% mniej zmetylowane w stosunku do DNA komórek osób zdrowych [18, 29, 30].

\section{Mutacje DNMT3A}

Gen DNMT3A (DNA (cytosine-5)-methyltransferase $3 A$ ) ulega mutacjom najczęściej spośród wszystkich genów metylotransferaz DNA [31]. Skutkiem mutacji DNMT3A jest hipometylacja niektórych regionów DNA. Mutacje DNMT3A występują monoallelicznie i mogą mieć charakter inaktywujący (całkowita utrata aktywności enzymatycznej) lub hipomorficzny (białko wykazuje częściową aktywność katalityczna). Do jednych z najczęściej występujących mutacji w $D N M T 3 A$ należą mutacje w pozycji argininy 882 mające charakter hipomorficzny i dominujący, gdyż zmutowane białko oddziałuje na aktywność metylotransferazową białka DNMT3A produkowanego przez allel niezmutowany [32,33]. Mutacje DNMT3A powiązano $z$ zaburzeniami ekspresji genów $H O X$ (homeobox), które kodują czynniki transkrypcyjne kluczowe w różnicowaniu i proliferacji komórek krwiotwórczych. Zaburzona ekspresja HOX może prowadzić do rozwoju wielu nowotworów, w tym AML [34-36]. Mutacje DNMT3A zostały zidentyfikowane u 12-35\% chorych z AML [20, 36-41]. $Z$ większości badań wynika, że obecność mutacji w DNMT3A pogarsza rokowanie chorych z AML poprzez zmniejszenie odsetka remisji, skrócenie całkowitego czasu przeżycia oraz zwiększenie częstości nawrotów choroby [40-44]. Mutacje DNMT3A występują częściej u chorych w starszym wieku, z wyższą leukocytozą i liczbą płytek krwi oraz ze współwystępującymi mutacjami NPM1, FLT3-ITD i IDH1. Mutacje DNMT3 zazwyczaj wiążą się z grupą AML o pośrednim rokowaniu, natomiast prawie nigdy nie występują $\mathrm{u}$ chorych $\mathrm{z}$ korzystną cytogenetyką [41]. Klinicznie istotne jest, że stwierdzenie obecności tej mutacji może świadczyć o wrażliwości na leczenie inhibitorami metylotransferaz DNA (DNMTi, DNA methytransferase inhibitors) $[45,46]$.

\section{Mutacje TET2}

Białko TET2 jest enzymem katalizującym oksydację 5-metylocytozyny (5-mc) do 5-hydroksymetylocytozyny $(5-\mathrm{hmc})[47,48]$. Cząsteczka 5 -hmc odgrywa istotną rolę $\mathrm{w}$ aktywnej oraz biernej demetylacji DNA. Pasywna demetylacja DNA zachodzi $z$ powodu braku wiązania 5 -hmc przez enzym DNMT1. Odpowiednie stężenie 5 -hmc w komórce umożliwia także aktywną demetylację DNA poprzez aktywację białek AID (activation-induced cytidine deaminase). Ponadto 5 -hmc hamuje metylację poprzez zablokowanie wiązania białek MDB (methyl-DNA binding proteins) do DNA, dodatkowo zapobiegając zmniejszeniu aktywności transkrypcyjnej [49-51]. Podwyższone stężenie 5-hmc w komórkach koreluje dodatnio ze stopniem ekspresji genów [52]. Mutacje TET2 uniemożliwiają przekształcenie 5-mc do 5-hmc, czego efektami są hipermetylacja DNA i obniżona ekspresja genów. Mutaje TET2 występują u 8-27\% chorych z AML. Ich obecność powiązano $z$ gorszym rokowaniem, szczególnie u chorych na AML pośredniego ryzyka [53, 54]. Występowanie mutacji TET2 u chorych z AML może się wiązać ze zwiększoną wrażliwością na terapię azacytydyną i decytabiną [55].

\section{Modyfikacje histonów}

Białka histonowe są ważnym składnikiem chromatyny i mogą podlegać zróżnicowanym modyfikacjom, takim jak acetylacja, metylacja, fosforylacja czy ubikwitynacja. Powyższe modyfikacje stanowią bardzo istotny element regulacji ekspresji genów $[10,56]$. Na podstawie badań nad wymienionymi wyżej procesami sformułowano hipotezę o tak zwanym kodzie histonowym. W myśl tej hipotezy zakłada się, że swoisty wzór modyfikacji histonów wywiera określony wpływ na ekspresję genów poprzez modulację struktury chromatyny oraz regulację aktywności transkrypcyjnej [57, 58]. Do najlepiej poznanych modyfikacji histonów zalicza się procesy acetylacji oraz metylacji.

\section{Acetylacja}

Acetylacja histonów jest przeprowadzana przez enzymy należące do acetylotransferaz histonowyh (HATs, histone acetyltransferases). Dołączenie reszt acetylowych prowadzi do wzrostu ladunku ujemnego histonów, powodując osłabienie wiązania białek histonowych $z$ DNA, a także oddziaływań między nukleosomami. Dlatego acetylacja histonów sprzyja powstawaniu rozluźnionej struktury chromatyny, co ułatwia wiązanie czynników transkrypcyjnych do DNA i ekspresję genów [59-61]. Z kolei deacetylacja histonów przebiega $z$ udziałem enzymów $z$ grupy deacetylaz histonowych (HDACs, histone deacetylases) i powoduje powstanie zamkniętej struktury chromatyny, a w konsekwencji - wyciszenie ekspresji genów [62, 63]. Zaburzenie balansu między acetylacją i deacetylacją histonów stanowi jedną $z$ cech transformacji nowotworowej, zaś zmieniony wzorzec acetylacji histonów można wykorzystywać do prognozowania przebiegu choroby [64]. W niektórych przypadkach HATs stają się elementami onkogennych białek fuzyjnych, na przykład $\mathrm{w}$ AML $\mathrm{z}$ translokacją $\mathrm{t}(8 ; 16)$ $(\mathrm{p} 11, \mathrm{p} 13) \mathrm{w}$ wyniku połączenia acetylotransferaz 
CBP (CREB-binding protein) i MOZ (monocytic leukemia zinc finger protein) dochodzi do powstania białka MOZ-CBP i w konsekwencji zaburzeń $\mathrm{w}$ acetylacji histonów $[65,66]$. Podobnie w przebiegu AML $z$ translokacją $(8 ; 21)$ oraz w ostrej białaczki promielocytowej powstające białka chimeryczne AML-ETO1 i PML-RAR $\alpha$ powodują nieprawidłową rekrutację HDACs, prowadząc do zaburzenia różnicowania komórkowego [67-69].

\section{Metylacja}

Metylacja histonów jest regulowana przez metylotransferazy (HMTs, histone methyltransferases) i demetylazy (HDMs, histone demethylases) histonowe, które odpowiednio dołączają lub odłączają reszty metylowe od wybranych reszt aminokwasowych histonów. Zmiany we wzorze metylacji histonów są częstym zjawiskiem obserwowanym podczas transformacji nowotworowej [70, 71]. W zależności od typów aminokwasów ulegających metylacji oraz stopnia ich metylacji proces ten może prowadzić do stymulacji lub zahamowania ekspresji genów [72].

\section{Mutacje EZH2}

Białko EZH2 (Enhancer of zeste homolog 2) to metylotransferaza histonowa należąca do kompleksu białek PRC2 (polycomb repressive complex). $Z$ kolei PRC2 jest jednym $z$ dwóch kompleksów białek Polycomb (PcG, Polycomb group), który pełni funkcję hamowania transkrypcji określonych genów poprzez modyfikację białek histonowych. Białko EZH2 odpowiada za metylację histonu H3 w pozycji 27 [73]. Mutacje genu EZH2 zidentyfikowano w wielu rodzajach nowotworów, w rozwoju których białko EZH2 może pełnić rolę onkogenu bądź genu supresorowego [74-79]. Mutacje EZH2 stwierdza się u około $2 \%$ chorych na AML $[20,80]$, a ich obecność może świadczyć o oporności choroby na leczenie. Inaktywację białka EZH2 stwierdzono w próbkach $45 \%$ pacjentów ze wznową AML [81]. Gen $E Z H 2$ jest zlokalizowany na długim ramieniu chromosomu 7, co może stanowić wytłumaczenie złego rokowania $u$ chorych $z$ delecją $7 q$ [82].

\section{Mutacje MLL}

Gen MLL (mixed-lineage leukemia) koduje metylotransferazę histonową MLL, która katalizuje metylację histonu $\mathrm{H} 3 \mathrm{w}$ pozycji K4. Białko MLL należy do kompleksu białek Trithorax (TrxG, Trithorax group), który pełni funkcję antagonistyczną w stosunku do białek PcG, utrzymując aktywność transkrypcyjną genów. Mutacje $M L L$ prowadzą między innymi do nadekspresji genów $H O X$, co skutkuje nieprawidłową proliferacją oraz różnicowaniem progenitorowych komórek macierzystych [83-85]. Gen $M L L$ ulega licznym translokacjom w przebiegu AML i ostrej białaczki limfoblastycznej. Translokacje $M L L$ występują u $5-10 \%$ pacjentów z AML. Mutacje genu $M L L$ wiążą się $z$ niekorzystnym przebiegiem choroby i opornością na leczenie [86-89].

\section{Mutacje ASXL1}

Gen ASXL1 (additional sex combs like 1) koduje słabo zdefiniowane do tej pory białko regulujące strukturę chromatyny, które może zarówno indukować, jak i hamować (np. poprzez interakcję $z$ kompleksem PRC) ekspresję wybranych genów. Mutacje $A S X L 1$, podobnie jak mutacje $M L L$, prowadzą do nadekspresji genów $H O X$ [90]. W AML mutacja $A S X L 1$ jest stwierdzana u 3-25\% chorych [91-96]. Obecność tej mutacji wiąże się $z$ gorszym rokowaniem [97-99]. Mutacje ASXL1 częściej są wykrywane u chorych powyżej 60 . roku życia [94, 100] oraz u pacjentów $z$ AML na podłożu innych chorób hematologicznych [101]. Niektóre badania wskazują, że współwystępowanie mutacji $A S X L 1$ oraz TET2 determinuje bardziej agresywny przebieg choroby [97]. Dodatkowo obecność mutacji ASXL1 może świadczyć o częściowej oporności na terapię azacytydyną [102, 103].

\section{Związek między epigenetyką a metabolizmem - mutacje IDH1 i IDH2}

Dehydrogenazy izocytrynianu 1 i 2 (IDH1/2, isocitrate dehydrogenase 1/2) są enzymami biorącymi udział w reakcji cyklu Krebsa prowadzącej do przekształcenia izocytrynianiu do $\alpha$-ketoglutaranu $(\alpha-\mathrm{KG})$. Mutacje w genach $I D H 1 / 2$ powodują, że zamiast $\alpha$-KG powstaje 2 -hydroksyglutaran (2-HG) o właściwościach onkometabolitu [104-106]. Dwuhydroksyglutaran hamuje aktywność HDMs oraz enzymów $z$ rodziny TET odpowiadających za metylację DNA [107, 108]. Skutkami zwiększonej produkcji 2-HG są zaburzona metylacja histonów oraz hipermetylacja DNA, która hamuje ekspresję genów supresorowych nowotworzenia. Mutacje genów IDH skutkują nadekspresją białek GATA1, zwiększoną regulacją c-KIT oraz zaburzeniem różnicowania komórek mieloidalnych [52].

Mutacje IDH1 stwierdza się u 6-16\% pacjentów z AML, natomiast mutacje IDH2 - u 8-19\% chorych [20, 91, 109-112]. Mutacje $I D H$ nigdy nie współwystępują u chorych z mutacjami TET2 [52, 53, 113]. Większość badań wykazała gorsze rokowanie u chorych $z$ mutacjami $I D H$ [110-112]. 
Zwiększone stężenie 2-HG powiązano $z$ gorszą odpowiedzią na leczenie oraz krótszym OS [107, 108, 114]. Podobnie jak mutacje DNMT3A, aberracje genów $I D H$ są częściej wykrywane u chorych obciążonych pośrednim ryzykiem cytogenetycznym. Mutacje $I D H$ na ogól stwierdza się u chorych w starszym wieku, z wyższą liczbą płytek krwi oraz obecnością mutacji NPM1 [110-112]. Obecnie inhibitory IDH są badane w kierunku zastosowania w ramach leczenia AML. Enasidenib (inhibitor IDH2) wprowadzono w terapii opornej, nawrotowej AML z obecnością mutacji IDH2 [115, 116].

\section{MicroRNA}

MicroRNA (miRNA) to dwudziestokilkunukleotydowe cząsteczki RNA, które łączą się z komplementarnymi fragmentami matrycowego RNA (mRNA), prowadząc do jego degradacji [117]. W ostatnim czasie wskazuje się na istotny wpływ zaburzeń ekspresji miRNA w patogenezie AML oraz MDS, które mogą pełnić rolę zarówno onkogenów, jak i genów supresorowych [118-121]. Proponuje się zastosowanie zmian w aktywności miRNA, między innymi do celów diagnostycznych, prognostycznych oraz leczniczych [122-125]. Sprecyzowanie roli miRNA w rozwoju AML oraz możliwości ich wykorzystania w przyszłości wymaga jeszcze przeprowadzenia wielu dodatkowych badań [126].

\section{Podsumowanie}

W ostatnich latach dynamiczny rozwój biologii molekularnej pozwolił na sprecyzowanie roli zaburzeń epigenetycznych w AML. Nieprawidłowa metylacja DNA i modyfikacja białek histonowych, poprzez zakłócenie transkrypcji genów, stanowią jeden z kluczowych elementów rozwoju AML. Obecnie wiadomo, że leukemogeneza wynika ze złożonych interakcji różnych zaburzeń genetycznych i epigenetycznych. Dzięki szczególowym badaniom molekularnym udało się wyodrębnić pojedyncze geny regulujące prawidłowy przebieg metylacji DNA (TET2, IDH1/2, DNMT3A) i modyfikacji białek histonowych (ASXL1, EZH2, MLL). Stwierdzenie mutacji we wspomnianych genach może pomóc $\mathrm{w}$ prognozowaniu przebiegu choroby oraz znalezieniu odpowiedzi na leczenie. Obecność wspomnianych wyżej mutacji może także w przyszłości posłużyć do ustalenia indywidualnego planu leczenia $z$ zastosowaniem leków celowanych. Wprowadzenie nowoczesnych leków epigenetycznych daje nadzieje na poprawę wyników leczenia u chorych na AML.

\section{Piśmiennictwo}

1. Estey E, Döhner H. Acute myeloid leukaemia. Lancet. 2006; 368(9550): 1894-1907, doi: 10.1016/S0140-6736(06)69780-8, indexed in Pubmed: 17126723.

2. Zhou HS, Carter BZ, Andreeff M. Bone marrow niche-mediated survival of leukemia stem cells in acute myeloid leukemia: Yin and Yang. Cancer Biol Med. 2016; 13(2): 248-259, doi: 10.20892/j. issn.2095-3941.2016.0023, indexed in Pubmed: 27458532.

3. Oran B, Weisdorf DJ. Survival for older patients with acute myeloid leukemia: a population-based study. Haematologica. 2012; 97(12): 1916-1924, doi: 10.3324/haematol.2012.066100, indexed in Pubmed: 22773600.

4. Burnett A, Wetzler M, Löwenberg B. Therapeutic advances in acute myeloid leukemia. J Clin Oncol. 2011; 29(5): 487-494, doi: 10.1200/JCO.2010.30.1820, indexed in Pubmed: 21220605.

5. Shah A, Andersson TML, Rachet B, et al. Survival and cure of acute myeloid leukaemia in England, 1971-2006: a populationbased study. Br J Haematol. 2013; 162(4): 509-516, doi: 10.1111/ bjh.12425, indexed in Pubmed: 23786647.

6. Klepin HD. Elderly acute myeloid leukemia: assessing risk. Curr Hematol Malig Rep. 2015; 10(2): 118-125, doi: 10.1007/s11899015-0257-2, indexed in Pubmed: 25939828.

7. Mrózek K, Carroll AJ, Maharry K, et al. Cytogenetics in acute leukemia. Blood Rev. 2004; 18(2): 115-136, doi: 10.1016/S0268960X(03)00040-7, indexed in Pubmed: 15010150.

8. Mardis ER, Ding Li, Dooling DJ, et al. Recurring mutations found by sequencing an acute myeloid leukemia genome. $\mathrm{N} \mathrm{Engl}$ J Med. 2009; 361(11): 1058-1066, doi: 10.1056/NEJMoa0903840, indexed in Pubmed: 19657110.

9. Welch JS, Petti AA, Miller CA, et al. The origin and evolution of mutations in acute myeloid leukemia. Cell. 2012; 150(2): 264-278, doi: 10.1016/j.cell.2012.06.023, indexed in Pubmed: 22817890.

10. Esteller M. Epigenetics in cancer. N Engl J Med. 2008; 358(11): 1148-1159, doi: 10.1056/NEJMra072067, indexed in Pubmed: 18337604.

11. Figueroa ME, Lugthart S, Li Y, et al. DNA methylation signatures identify biologically distinct subtypes in acute myeloid leukemia. Cancer Cell. 2010; 17(1): 13-27, doi: 10.1016/j.ccr.2009.11.020, indexed in Pubmed: 20060365.

12. Jones PA, Baylin SB. The epigenomics of cancer. Cell. 2007; 128(4): 683-692, doi: 10.1016/j.cell.2007.01.029, indexed in Pubmed: 17320506 .

13. Gutierrez SE, Romero-Oliva FA. Epigenetic changes: a common theme in acute myelogenous leukemogenesis. J Hematol Oncol. 2013; 6: 57, doi: 10.1186/1756-8722-6-57, indexed in Pubmed: 23938080.

14. Egger G, Liang G, Aparicio A, et al. Epigenetics in human disease and prospects for epigenetic therapy. Nature. 2004; 429(6990): 457-463, doi: 10.1038/nature02625, indexed in Pubmed: 15164071 .

15. Tollervey JR, Lunyak VV. Epigenetics: judge, jury and executioner of stem cell fate. Epigenetics. 2012; 7(8): 823-840, doi: 10.4161/ epi.21141, indexed in Pubmed: 22805743.

16. Fong CY, Morison J, Dawson MA. Epigenetics in the hematologic malignancies. Haematologica. 2014; 99(12): 1772-1783, doi: 10.3324/haematol.2013.092007, indexed in Pubmed: 25472952.

17. Greenblatt SM, Nimer SD. Chromatin modifiers and the promise of epigenetic therapy in acute leukemia. Leukemia. 2014; 28(7): 1396-1406, doi: 10.1038/leu.2014.94, indexed in Pubmed: 24609046. 
18. Łukasik M, Karmalska J, Szutowski MM, et al. Wpływ metylacji DNA na funkcjonowanie genomu. Biuletyn Wydziału Farmaceutycznego Warszawskiego Uniwersytetu Medycznego. 2009; 2: 13-18.

19. Lopez-Serra L, Esteller M. Proteins that bind methylated DNA and human cancer: reading the wrong words. Br J Cancer. 2008; 98(12): 1881-1885, doi: 10.1038/sj.bjc.6604374, indexed in Pubmed: 18542062 .

20. Ley TJ, Miller C, Ding Li, et al. Cancer Genome Atlas Research Network. Genomic and epigenomic landscapes of adult de novo acute myeloid leukemia. N Engl J Med. 2013; 368(22): 2059-2074, doi: 10.1056/NEJMoa1301689, indexed in Pubmed: 23634996.

21. Baylin SB, Jones PA. A decade of exploring the cancer epigenome - biological and translational implications. Nat Rev Cancer. 2011; 11(10): 726-734, doi: 10.1038/nrc3130, indexed in Pubmed: 21941284 .

22. Kroeger H, Jelinek J, Estécio MRH, et al. Aberrant CpG island methylation in acute myeloid leukemia is accentuated at relapse. Blood. 2008; 112(4): 1366-1373, doi: 10.1182/ blood-2007-11-126227, indexed in Pubmed: 18523155.

23. Qu Y, Lennartsson A, Gaidzik VI, et al. Differential methylation in CN-AML preferentially targets non-CGI regions and is dictated by DNMT3A mutational status and associated with predominant hypomethylation of HOX genes. Epigenetics. 2014; 9(8): 1108-1119, doi: 10.4161/epi.29315, indexed in Pubmed: 24866170.

24. Toyota M, Ahuja N, Ohe-Toyota M, et al. CpG island methylator phenotype in colorectal cancer. Proc Natl Acad Sci USA. 1999; 96(15): 8681-8686, doi: 10.1073/pnas.96.15.8681.

25. Boyes J, Bird A. DNA methylation inhibits transcription indirectly via a methyl-CpG binding protein. Cell. 1991; 64(6): 1123-1134, indexed in Pubmed: 2004419.

26. Watt F, Molloy PL. Cytosine methylation prevents binding to DNA of a HeLa cell transcription factor required for optimal expression of the adenovirus major late promoter. Genes Dev. 1988; 2(9): 1136-1143, indexed in Pubmed: 3192075.

27. Gonzalgo ML, Jones PA. Mutagenic and epigenetic effects of DNA methylation. Mutat Res. 1997; 386(2): 107-118, indexed in Pubmed: 9113112.

28. Shen L, Kantarjian H, Guo Yi, et al. DNA methylation predicts survival and response to therapy in patients with myelodysplastic syndromes. J Clin Oncol. 2010; 28(4): 605-613, doi: 10.1200/ JCO.2009.23.4781, indexed in Pubmed: 20038729.

29. Ehrlich M. DNA hypomethylation in cancer cells. Epigenomics. 2009; 1(2): 239-259, doi: 10.2217/epi.09.33, indexed in Pubmed: 20495664.

30. Saied MH, Marzec J, Khalid S, et al. Genome wide analysis of acute myeloid leukemia reveal leukemia specific methylome and subtype specific hypomethylation of repeats. PLoS One. 2012; 7(3): e33213, doi: 10.1371/journal.pone.0033213, indexed in Pubmed: 22479372 .

31. Chan SM, Majeti R. Role of DNMT3A, TET2, and IDH1/2 mutations in pre-leukemic stem cells in acute myeloid leukemia. Int J Hematol. 2013; 98(6): 648-657, doi: 10.1007/s12185-013-14078, indexed in Pubmed: 23949914.

32. Yamashita Y, Yuan J, Suetake I, et al. Array-based genomic resequencing of human leukemia. Oncogene. 2010; 29(25): 3723-3731, doi: 10.1038/onc.2010.117, indexed in Pubmed: 20400977.

33. Ley TJ, Ding Li, Walter MJ, et al. DNMT3A mutations in acute myeloid leukemia. N Engl J Med. 2010; 363(25): 2424-2433, doi: 10.1056/NEJMoa1005143, indexed in Pubmed: 21067377.
34. Rice KL, Licht JD. HOX deregulation in acute myeloid leukemia. J Clin Invest. 2007; 117(4): 865-868, doi: 10.1172/JCI31861, indexed in Pubmed: 17404613.

35. Alharbi RA, Pettengell R, Pandha HS, et al. The role of HOX genes in normal hematopoiesis and acute leukemia. Leukemia. 2013; 27(5): 1000-1008, doi: 10.1038/leu.2012.356, indexed in Pubmed: 23212154.

36. Shah N, Sukumar S. The Hox genes and their roles in oncogenesis. Nat Rev Cancer. 2010; 10(5): 361-371, doi: 10.1038/nrc2826, indexed in Pubmed: 20357775.

37. Challen GA, Sun D, Jeong M, et al. Dnmt3a is essential for hematopoietic stem cell differentiation. Nat Genet. 2011; 44(1): 23-31, doi: 10.1038/ng.1009, indexed in Pubmed: 22138693.

38. Marcucci G, Metzeler KH, Schwind S, et al. Age-related prognostic impact of different types of DNMT3A mutations in adults with primary cytogenetically normal acute myeloid leukemia. J Clin Oncol. 2012; 30(7): 742-750, doi: 10.1200/JCO.2011.39.2092, indexed in Pubmed: 22291079.

39. Hájková H, Marková J, Haškovec C, et al. Decreased DNA methylation in acute myeloid leukemia patients with DNMT3A mutations and prognostic implications of DNA methylation. Leuk Res. 2012; 36(9): 1128-1133, doi: 10.1016/j.leukres.2012.05.012, indexed in Pubmed: 22749068.

40. Thol F, Damm F, Lüdeking A, et al. Incidence and prognostic influence of DNMT3A mutations in acute myeloid leukemia. J Clin Oncol. 2011; 29(21): 2889-2896, doi: 10.1200/JCO.2011.35.4894, indexed in Pubmed: 21670448.

41. Yuan XQ, Peng Li, Zeng WJ, et al. DNMT3A R882 mutations predict a poor prognosis in AML: a meta-analysis from 4474 patients. Medicine (Baltimore). 2016; 95(18): e3519, doi: 10.1097/ MD.0000000000003519, indexed in Pubmed: 27149454.

42. Hopfer O, Komor M, Koehler IS, et al. Aberrant promotor methylation in MDS hematopoietic cells during in vitro lineage specific differentiation is differently associated with DNMT isoforms. Leuk Res. 2009; 33(3): 434-442, doi: 10.1016/j.leukres.2008.08.014, indexed in Pubmed: 18829110.

43. Ribeiro AF, Pratcorona M, Erpelinck-Verschueren C, et al. Mutant DNMT3A: a marker of poor prognosis in acute myeloid leukemia. Blood. 2012; 119(24): 5824-5831, doi: 10.1182/ blood-2011-07-367961, indexed in Pubmed: 22490330.

44. Walter MJ, Ding L, Shen D, et al. Recurrent DNMT3A mutations in patients with myelodysplastic syndromes. Leukemia. 2011; 25(7): 1153-1158, doi: 10.1038/leu.2011.44, indexed in Pubmed: 21415852.

45. Traina F, Visconte V, Elson P, et al. Impact of molecular mutations on treatment response to DNMT inhibitors in myelodysplasia and related neoplasms. Leukemia. 2014; 28(1): 78-87, doi: 10.1038/ leu.2013.269, indexed in Pubmed: 24045501.

46. Metzeler KH, Walker A, Geyer S, et al. DNMT3A mutations and response to the hypomethylating agent decitabine in acute myeloid leukemia. Leukemia. 2012; 26(5): 1106-1107, doi: 10.1038/ leu.2011.342, indexed in Pubmed: 22124213.

47. Tahiliani M, Koh KP, Shen Y, et al. Conversion of 5-methylcytosine to 5-hydroxymethylcytosine in mammalian DNA by MLL partner TET1. Science. 2009; 324(5929): 930-935, doi: 10.1126/ science.1170116, indexed in Pubmed: 19372391.

48. Ito S, D’Alessio AC, Taranova OV, et al. Role of Tet proteins in $5 \mathrm{mC}$ to $5 \mathrm{hmC}$ conversion, ES-cell self-renewal and in ner cell mass specification. Nature. 2010; 466(7310): 1129-1133, doi: 10.1038/nature09303, indexed in Pubmed: 20639862 . 
49. Valinluck V, Sowers LC. Endogenous cytosine damage products alter the site selectivity of human DNA maintenance methyltransferase DNMT1. Cancer Res. 2007; 67(3): 946-950, doi: 10.1158/00085472.CAN-06-3123, indexed in Pubmed: 17283125.

50. Valinluck V, Tsai HH, Rogstad DK, et al. Oxidative damage to methyl-CpG sequences inhibits the binding of the methyl-CpG binding domain (MBD) of methyl-CpG binding protein 2 (MeCP2). Nucleic Acids Res. 2004; 32(14): 4100-4108, doi: 10.1093/nar/ gkh739, indexed in Pubmed: 15302911.

51. Pastor WA, Pape UJ, Huang Y, et al. Genome-wide mapping of 5-hydroxymethylcytosine in embryonic stem cells. Nature. 2011; 473(7347): 394-397, doi: 10.1038/nature10102, indexed in Pubmed: 21552279.

52. Figueroa ME, Abdel-Wahab O, Lu C, et al. Leukemic IDH1 and IDH2 mutations result in a hypermethylation phenotype, disrupt TET2 function, and impair hematopoietic differentiation. Cancer Cell. 2010; 18(6): 553-567, doi: 10.1016/j.ccr.2010.11.015, indexed in Pubmed: 21130701.

53. Metzeler KH, Maharry K, Radmacher MD, et al. TET2 mutations improve the new European LeukemiaNet risk classification of acute myeloid leukemia: a Cancer and Leukemia Group B study. J Clin Oncol. 2011; 29(10): 1373-1381, doi: 10.1200/ JCO.2010.32.7742, indexed in Pubmed: 21343549.

54. Patel KP, Ravandi F, Ma D. Acute myeloid leukemia with IDH1 or IDH2 mutation: frequency and clinicopathologic features. Am J Clin Pathol. 2011; 135(1): 35-45, doi: 10.1309/AJCPD7NR2RMNQDVF, indexed in Pubmed: 21173122.

55. Bejar R, Lord A, Stevenson K, et al. TET2 mutations predict response to hypomethylating agents in myelodysplastic syndrome patients. Blood. 2014; 124(17): 2705-2712, doi: 10.1182/ blood-2014-06-582809, indexed in Pubmed: 25224413.

56. Kouzarides T. Chromatin modifications and their function. Cell. 2007; 128(4): 693-705, doi: 10.1016/j.cell.2007.02.005, indexed in Pubmed: 17320507.

57. Wang Y, Fischle W, Cheung W, et al. Beyond the double helix: writing and reading the histone code. Novartis Found Symp. 2004; 259: 3-17; discussion 17, indexed in Pubmed: 15171244.

58. de la Cruz X, Lois S, Sánchez-Molina S, et al. Do protein motifs read the histone code? Bioessays. 2005; 27(2): 164-175, doi: 10.1002/bies.20176, indexed in Pubmed: 15666348.

59. Sterner DE, Berger SL. Acetylation of histones and transcriptionrelated factors. Microbiol Mol Biol Rev. 2000; 64(2): 435-459, indexed in Pubmed: 10839822.

60. Vettese-Dadey M, Grant PA, Hebbes TR, et al. Acetylation of histone $\mathrm{H} 4$ plays a primary role in enhancing transcription factor binding to nucleosomal DNA in vitro. EMBO J. 1996; 15(10): 2508-2518, indexed in Pubmed: 8665858.

61. Lee JY, Lee TH. Effects of histone acetylation and CpG methylation on the structure of nucleosomes. Biochim Biophys Acta. 2012; 1824: 974-982.

62. Delcuve GP, Khan DH, Davie JR. Roles of histone deacetylases in epigenetic regulation: emerging paradigms from studies with inhibitors. Clin Epigenetics. 2012; 4(1): 5, doi: 10.1186/1868-70834-5, indexed in Pubmed: 22414492.

63. Verdin E, Ott M. 50 years of protein acetylation: from gene regulation to epigenetics, metabolism and beyond. Nat Rev Mol Cell Biol. 2015; 16(4): 258-264, doi: 10.1038/nrm3931, indexed in Pubmed: 25549891.

64. Advani AS, Gibson SE, Douglas E, et al. Histone H4 acetylation by immunohistochemistry and prognosis in newly diagnosed adult acute lymphoblastic leukemia (ALL) patients. BMC Cancer.
2010; 10: 387, doi: 10.1186/1471-2407-10-387, indexed in Pubmed: 20663136.

65. Rozman M, Camós M, Colomer D, et al. Type I MOZ/CBP (MYST3/CREBBP) is the most common chimeric transcript in acute myeloid leukemia with $\mathrm{t}(8 ; 16)(\mathrm{p} 11 ; \mathrm{p} 13)$ translocation. Genes Chromosomes Cancer. 2004; 40(2): 140-145, doi: 10.1002/ gcc.20022, indexed in Pubmed: 15101047.

66. Deguchi K, Ayton PM, Carapeti M, et al. MOZ-TIF2-induced acute myeloid leukemia requires the $\mathrm{MOZ}$ nucleosome binding motif and TIF2-mediated recruitment of CBP. Cancer Cell. 2003; 3(3): 259-271, indexed in Pubmed: 12676584.

67. Izutsu K, Kurokawa M, Imai Y, et al. The corepressor CtBP interacts with Evi-1 to repress transforming growth factor beta signaling. Blood. 2001; 97(9): 2815-2822, indexed in Pubmed: 11313276.

68. Martens JHA, Brinkman AB, Simmer F, et al. PML-RARalpha/ /RXR alters the epigenetic landscape in acute promyelocytic leukemia. Cancer Cell. 2010; 17(2): 173-185, doi: 10.1016/j. ccr.2009.12.042, indexed in Pubmed: 20159609.

69. Minucci S, Nervi C, Lo Coco F, et al. Histone deacetylases: a common molecular target for differentiation treatment of acute myeloid leukemias? Oncogene. 2001; 20(24): 3110-3115, doi: 10.1038/sj.onc.1204336, indexed in Pubmed: 11420727.

70. Castelli G, Pelosi E, Testa U. Targeting histone methyltransferase and demethylase in acute myeloid leukemia therapy. Onco Targets Ther. 2018; 11: 131-155, doi: 10.2147/OTT.S145971, indexed in Pubmed: 29343972.

71. Esteller M. Cancer epigenomics: DNA methylomes and histone-modification maps. Nat Rev Genet. 2007; 8(4): 286-298, doi: 10.1038/nrg2005, indexed in Pubmed: 17339880.

72. Cheung N, So CW. Transcriptional and epigenetic networks in haematological malignancy. FEBS Lett. 2011; 585(13): 2100-2111, doi: 10.1016/j.febslet.2011.03.068, indexed in Pubmed: 21477587.

73. Kuzmichev A, Jenuwein T, Tempst P, et al. Different EZH2containing complexes target methylation of histone $\mathrm{H} 1$ or nucleosomal histone H3. Mol Cell. 2004; 14(2): 183-193, indexed in Pubmed: 15099518.

74. Ernst T, Chase AJ, Score J, et al. Inactivating mutations of the histone methyltransferase gene EZH2 in myeloid disorders. Nat Genet. 2010; 42(8): 722-726, doi: 10.1038/ng.621, indexed in Pubmed: 20601953.

75. Nikoloski G, Langemeijer SMC, Kuiper RP, et al. Somatic mutations of the histone methyltransferase gene EZH2 in myelodysplastic syndromes. Nat Genet. 2010; 42(8): 665-667, doi: 10.1038/ ng.620, indexed in Pubmed: 20601954.

76. Tanaka S, Miyagi S, Sashida G, et al. Ezh2 augments leukemogenicity by reinforcing differentiation blockage in acute myeloid leukemia. Blood. 2012; 120(5): 1107-1117, doi: 10.1182/ blood-2011-11-394932, indexed in Pubmed: 22677129.

77. Herrera-Merchan A, Arranz L, Ligos JM, et al. Ectopic expression of the histone methyltransferase Ezh2 in haematopoietic stem cells causes myeloproliferative disease. Nat Commun. 2012; 3: 623, doi: 10.1038/ncomms1623, indexed in Pubmed: 22233633.

78. Simon JA, Lange CA. Roles of the EZH2 histone methyltransferase in cancer epigenetics. Mutat Res. 2008; 647(1-2): 21-29, doi: 10.1016/j. mrfmmm.2008.07.010, indexed in Pubmed: 18723033.

79. Morin RD, Johnson NA, Severson TM, et al. Somatic mutations altering EZH2 (Tyr641) in follicular and diffuse large B-cell lymphomas of germinal-center origin. Nat Genet. 2010; 42(2): 181-185, doi: 10.1038/ng.518, indexed in Pubmed: 20081860.

80. Wang X, Dai H, Wang Q, et al. EZH2 mutations are related to low blast percentage in bone marrow and $-7 / \operatorname{del}(7 q)$ in de novo acute 
myeloid leukemia. PLoS One. 2013; 8(4): e61341, doi: 10.1371/ journal.pone.0061341, indexed in Pubmed: 23613835.

81. Göllner S, Oellerich T, Agrawal-Singh S, et al. Loss of the histone methyltransferase EZH2 induces resistance to multiple drugs in acute myeloid leukemia. Nat Med. 2017; 23(1): 69-78, doi: 10.1038/nm.4247, indexed in Pubmed: 27941792.

82. Le Beau MM, Espinosa R, Davis EM, et al. Cytogenetic and molecular delineation of a region of chromosome 7 commonly deleted in malignant myeloid diseases. Blood. 1996; 88(6): 1930-1935, indexed in Pubmed: 8822909.

83. Ringrose L, Paro R. Epigenetic regulation of cellular memory by the Polycomb and Trithorax group proteins. Annu Rev Genet. 2004; 38: 413-443, doi: 10.1146/annurev.genet.38.072902.091907, indexed in Pubmed: 15568982.

84. Hess JL. MLL: a histone methyltransferase disrupted in leukemia. Trends Mol Med. 2004; 10(10): 500-507, doi: 10.1016/j. molmed.2004.08.005, indexed in Pubmed: 15464450.

85. Krivtsov AV, Armstrong SA. MLL translocations, histone modifications and leukaemia stem-cell development. Nat Rev Cancer. 2007; 7(11): 823-833, doi: 10.1038/nrc2253, indexed in Pubmed: 17957188 .

86. Marschalek R. Mixed lineage leukemia: roles in human malignancies and potential therapy. FEBS J. 2010; 277(8): 18221831, doi: $10.1111 / \mathrm{j} .1742-4658.2010 .07608 . x$, indexed in Pubmed: 20236311.

87. Zeisig BB, So CW. Cellular and molecular basis of KMT2A/MLL leukaemias: from transformation mechanisms to novel therapeutic strategies. In: Rowley JD, Le Beau MM, Rabbitts TH. ed. Chromosomal translocations and genome rearrangements in cancer. Springer, New York 2016: 223-250.

88. Döhner K, Tobis K, Ulrich R, et al. Prognostic significance of partial tandem duplications of the MLL gene in adult patients 16 to 60 years old with acute myeloid leukemia and normal cytogenetics: a study of the Acute Myeloid Leukemia Study Group Ulm. J Clin Oncol. 2002; 20(15): 3254-3261, doi: 10.1200/JCO.2002.09.088, indexed in Pubmed: 12149299.

89. Harrison CJ, Griffiths M, Moorman F, et al. A multicenter evaluation of comprehensive analysis of MLL translocations and fusion gene partners in acute leukemia using the MLL FusionChip device. Cancer Genet Cytogenet. 2007; 173(1): 17-22, doi: 10.1016/j. cancergencyto.2006.09.006, indexed in Pubmed: 17284365.

90. Abdel-Wahab O, Adli M, LaFave LM, et al. ASXL1 mutations promote myeloid transformation through loss of PRC2-mediated gene repression. Cancer Cell. 2012; 22(2): 180-193, doi: 10.1016/j. ccr.2012.06.032, indexed in Pubmed: 22897849.

91. Patel JP, Gönen M, Figueroa ME, et al. Prognostic relevance of integrated genetic profiling in acute myeloid leukemia. N Engl J Med. 2012; 366(12): 1079-1089, doi: 10.1056/NEJMoa1112304, indexed in Pubmed: 22417203.

92. Boultwood J, Perry J, Pellagatti A, et al. Frequent mutation of the polycomb-associated gene ASXL1 in the myelodysplastic syndromes and in acute myeloid leukemia. Leukemia. 2010; 24(5): 1062-1065, doi: 10.1038/leu.2010.20, indexed in Pubmed: 20182461.

93. Rocquain J, Carbuccia N, Trouplin V, et al. Combined mutations of ASXL1, CBL, FLT3, IDH1, IDH2, JAK2, KRAS, NPM1, NRAS, RUNX1, TET2 and WT1 genes in myelodysplastic syndromes and acute myeloid leukemias. BMC Cancer. 2010; 10: 401, doi: 10.1186/1471-2407-10-401, indexed in Pubmed: 20678218.

94. Metzeler KH, Becker H, Maharry K, et al. ASXL1 mutations identify a high-risk subgroup of older patients with primary cytogenetically normal AML within the ELN Favorable genetic category. Blood. 2011; 118(26): 6920-6929, doi: 10.1182/ blood-2011-08-368225, indexed in Pubmed: 22031865.

95. Schnittger S, Eder C, Jeromin S, et al. ASXL1 exon 12 mutations are frequent in AML with intermediate risk karyotype and are independently associated with an adverse outcome. Leukemia. 2013; 27(1): 82-91, doi: 10.1038/leu.2012.262, indexed in Pubmed: 23018865.

96. Paschka P, Schlenk RF, Gaidzik VI, et al. ASXL1 mutations in younger adult patients with acute myeloid leukemia: a study by the German-Austrian Acute Myeloid Leukemia Study Group. Haematologica. 2015; 100(3): 324-330, doi: 10.3324/haematol.2014.114157, indexed in Pubmed: 25596267.

97. Abdel-Wahab O, Levine RL. Mutations in epigenetic modifiers in the pathogenesis and therapy of acute myeloid leukemia. Blood. 2013; 121(18): 3563-3572, doi: 10.1182/blood-2013-01-451781, indexed in Pubmed: 23640996.

98. Katoh M. Functional and cancer genomics of ASXL family members. Br J Cancer. 2013; 109(2): 299-306, doi: 10.1038/ bjc.2013.281, indexed in Pubmed: 23736028.

99. Pratcorona M, Abbas S, Sanders MA, et al. Acquired mutations in ASXL1 in acute myeloid leukemia: prevalence and prognostic value. Haematologica. 2012; 97(3): 388-392, doi: 10.3324/haematol.2011.051532, indexed in Pubmed: 22058207.

100. Abdel-Wahab O, Kilpivaara O, Patel J, et al. The most commonly reported variant in ASXL1 (c.1934dupG;p.Gly646TrpfsX12) is not a somatic alteration. Leukemia. 2010; 24(9): 1656-1657, doi: 10.1038/leu.2010.144, indexed in Pubmed: 20596031.

101. Abdel-Wahab O, Manshouri T, Patel J, et al. Genetic analysis of transforming events that convert chronic myeloproliferative neoplasms to leukemias. Cancer Res. 2010; 70(2): 447452, doi: 10.1158/0008-5472.CAN-09-3783, indexed in Pubmed: 20068184.

102. Bejar R, Stevenson K, Stojanov P, et al. O-024 Next-generation sequencing of 213 MDS patient samples identifies mutation profiles associated with response to hypomethylating agents and overall survival. Leuk Res. 2013; 37: S19-S20, doi: 10.1016/ s0145-2126(13)70046-8.

103. Itzykson R, Kosmider O, Cluzeau T, et al. Groupe Francophone des Myelodysplasies (GFM). Impact of TET2 mutations on response rate to azacitidine in myelodysplastic syndromes and low blast count acute myeloid leukemias. Leukemia. 2011; 25(7): 1147-1152, doi: 10.1038/leu.2011.71, indexed in Pubmed: 21494260.

104. Reitman ZJ, Yan H. Isocitrate dehydrogenase 1 and 2 mutations in cancer: alterations at a crossroads of cellular metabolism. J Natl Cancer Inst. 2010; 102(13): 932-941, doi: 10.1093/jnci/djq187, indexed in Pubmed: 20513808.

105. Dang L, White DW, Gross S, et al. Cancer-associated IDH1 mutations produce 2-hydroxyglutarate. Nature. 2009; 462(7274): 739 -744, doi: 10.1038/nature08617, indexed in Pubmed: 19935646.

106. Ward PS, Patel J, Wise DR, et al. The common feature of leukemia-associated IDH1 and IDH2 mutations is a neomorphic enzyme activity converting alpha-ketoglutarate to 2-hydroxyglutarate. Cancer Cell. 2010; 17(3): 225-234, doi: 10.1016/j. ccr.2010.01.020, indexed in Pubmed: 20171147.

107. Gross S, Cairns RA, Minden MD, et al. Cancer-associated metabolite 2-hydroxyglutarate accumulates in acute myelogenous leukemia with isocitrate dehydrogenase 1 and 2 mutations. J Exp Med. 2010; 207(2): 339-344, doi: 10.1084/jem.20092506, indexed in Pubmed: 20142433. 
108. Reitman ZJ, Parsons DW, Yan H. IDH1 and IDH2: not your typical oncogenes. Cancer Cell. 2010; 17(3): 215-216, doi: 10.1016/j. ccr.2010.02.024, indexed in Pubmed: 20227034.

109. Shen Y, Zhu YM, Fan X, et al. Gene mutation patterns and their prognostic impact in a cohort of 1185 patients with acute myeloid leukemia. Blood. 2011; 118(20): 5593-5603, doi: 10.1182/ blood-2011-03-343988, indexed in Pubmed: 21881046.

110. Abbas S, Lugthart S, Kavelaars FG, et al. Acquired mutations in the genes encoding IDH1 and IDH2 both are recurrent aberrations in acute myeloid leukemia: prevalence and prognostic value. Blood. 2010; 116(12): 2122-2126, doi: 10.1182/ blood-2009-11-250878, indexed in Pubmed: 20538800.

111. Paschka P, Schlenk RF, Gaidzik VI, et al. IDH1 and IDH2 mutations are frequent genetic alterations in acute myeloid leukemia and confer adverse prognosis in cytogenetically normal acute myeloid leukemia with NPM1 mutation without FLT3 internal tandem duplication. J Clin Oncol. 2010; 28(22): 3636-3643, doi: 10.1200/JCO.2010.28.3762, indexed in Pubmed: 20567020.

112. Marcucci G, Maharry K, Wu YZ, et al. IDH1 and IDH2 gene mutations identify novel molecular subsets within de novo cytogenetically normal acute myeloid leukemia: a Cancer and Leukemia Group B study. J Clin Oncol. 2010; 28(14): 2348-2355, doi: 10.1200/JCO.2009.27.3730, indexed in Pubmed: 20368543.

113. Xu W, Yang H, Liu Y, et al. Oncometabolite 2-hydroxyglutarate is a competitive inhibitor of $\alpha$-ketoglutarate-dependent dioxygenases. Cancer Cell. 2011; 19(1): 17-30, doi: 10.1016/j.ccr.2010.12.014, indexed in Pubmed: 21251613.

114. DiNardo CD, Propert KJ, Loren AW, et al. Serum 2-hydroxyglutarate levels predict isocitrate dehydrogenase mutations and clinical outcome in acute myeloid leukemia. Blood. 2013; 121(24): 4917-4924, doi: 10.1182/blood-2013-03-493197, indexed in Pubmed: 23641016

115. DiNardo CD, de Botton S, Stein EM, et al. Ivosidenib (AG-120) in mutant IDH1 AML and advanced hematologic malignancies: results of a phase 1 dose escalation and expansion study. Blood. 2017; $130: 725$.

116. Nassereddine S, Lap CJ, Haroun F, et al. The role of mutant IDH1 and IDH2 inhibitors in the treatment of acute myeloid leukemia. Ann Hematol. 2017; 96(12): 1983-1991, doi: 10.1007/s00277-0173161-0, indexed in Pubmed: 29090344.
117. Vasilatou D, Papageorgiou S, Pappa V, et al. The role of microRNAs in normal and malignant hematopoiesis. Eur J Haematol. 2010; 84(1): 1-16, doi: 10.1111/j.1600-0609.2009.01348.x, indexed in Pubmed: 19744129.

118. Jongen-Lavrencic M, Sun SuM, Dijkstra MK, et al. MicroRNA expression profiling in relation to the genetic heterogeneity of acute myeloid leukemia. Blood. 2008; 111(10): 5078-5085, doi: 10.1182/ blood-2008-01-133355, indexed in Pubmed: 18337557.

119. Garzon R, Liu S, Fabbri M, et al. MicroRNA-29b induces global DNA hypomethylation and tumor suppressor gene reexpression in acute myeloid leukemia by targeting directly DNMT3A and 3B and indirectly DNMT1. Blood. 2009; 113(25): 6411-6418, doi: 10.1182/ blood-2008-07-170589, indexed in Pubmed: 19211935.

120. Ufkin ML, Peterson S, Yang X, et al. miR-125a regulates cell cycle, proliferation, and apoptosis by targeting the ErbB pathway in acute myeloid leukemia. Leuk Res. 2014; 38(3): 402-410, doi: 10.1016/j.leukres.2013.12.021, indexed in Pubmed: 24484870 .

121. Winter J, Diederichs S. MicroRNA biogenesis and cancer. Methods Mol Biol. 2011; 676: 3-22, doi: 10.1007/978-1-60761-863-8_1, indexed in Pubmed: 20931386.

122. Li Z, Lu J, Sun M, et al. Distinct microRNA expression profiles in acute myeloid leukemia with common translocations. Proc Natl Acad Sci U S A. 2008; 105(40): 15535-15540, doi: 10.1073/ pnas.0808266105, indexed in Pubmed: 18832181.

123. Mendler JH, Maharry K, Radmacher MD, et al. MicroRNA expression in cytogenetically normal acute myeloid leukemia. N Engl J Med. 2008; 358(18): 1919-1928, doi: 10.1056/NEJMoa074256, indexed in Pubmed: 18450603.

124. Gong JN, Yu J, Lin HS, et al. The role, mechanism and potentially therapeutic application of microRNA-29 family in acute myeloid leukemia. Cell Death Differ. 2014; 21(1): 100-112, doi: 10.1038/ cdd.2013.133, indexed in Pubmed: 24076586.

125. Su R, Lin HS, Zhang XH, et al. MiR-181 family: regulators of myeloid differentiation and acute myeloid leukemia as well as potential therapeutic targets. Oncogene. 2015; 34(25): 3226-3239, doi: 10.1038/onc.2014.274, indexed in Pubmed: 25174404.

126. Chung SS, Park CY. MicroRNA dysregulation in the myelodysplastic syndromes. Microrna. 2014; 2(3): 174-186, indexed in Pubmed: 25069441. 